\title{
Assessment of clinical risk factors for drug-resistant epilepsy in children and teenagers
}

\section{Ocena klinicznych czynników ryzyka wystąienia padaczki lekoopornej u dzieci i młodzieży}

\author{
Marta Kasprzyk¹, Waldemar Brola ${ }^{1}$, Janusz Wendorff² \\ ${ }^{1}$ Neurology Department with Stroke Unit, Specialist Hospital, Końskie, Poland \\ Head of Department: Prof. Waldemar Brola MD, PhD \\ ${ }^{2}$ Copernicus Memorial Hospital, Lodz, Poland \\ Head of Hospital: Wojciech Szrajber
}

Key words: risk factors, epilepsy, drug resistance.

Słowa kluczowe: czynniki ryzyka, padaczka, lekooporność.

\begin{abstract}
Introduction: Epilepsy is one of the most common neurological illnesses occurring in children. In approximately $20-30 \%$ of cases it is drug-resistant.

Aim of the research: To assess the already-known risk factors, analyse the rarely described ones, and find new causes of epilepsy drug resistance in children, taking into account the level of impact of each factor.

Material and methods: The study comprised 152 of all 383 children hospitalised in 2012 at the Neurology Department of the Polish Mother's Memorial Hospital in Lodz due to epilepsy. Based on medical documentation, neurological examination, and our own questionnaire, we divided patients into two groups: drug-resistant epilepsy or drug-sensitive epilepsy. We compared the type, level of influence, and prevalence of different factors. For statistical analysis, the $\chi^{2}$ test was used. Statistical significance was set at $p<0.05$.

Results: Drug-resistant epilepsy was found in 64 patients (42.1\%), and drug-sensitive epilepsy was found in 88 patients (57.9\%). Factors that were most probable to cause drug resistance included: high prevalence of seizures (Cramer's $\mathrm{V}=0.66$ ), type of epileptic syndrome $(\mathrm{V}=0.62)$, psychomotor developmental delay $(\mathrm{V}=0.62)$, and occurrence of status epilepticus $(\mathrm{V}=0.6)$. Factors such as infections of CNS in early childhood, repeated severe infections of airways in childhood, and mother's infectious diseases with high fever during pregnancy were rare or non occurring (Cramer's V $=0.41,0.32$, and 0.31 , respectively).

Conclusions: The study confirmed the previously known causes of drug resistance and indicated the significance of underestimated inflammatory and infectious factors involving pyrexia, in children and also in mothers during pregnancy.
\end{abstract}

\section{Streszczenie}

Wprowadzenie: Padaczka jest jedną z najczęstszych chorób neurologicznych u dzieci. Około 20-30\% przypadków padaczki nie poddaje się leczeniu. Wciąż poszukuje się czynników ryzyka lekooporności.

Cel pracy: Ocena znanych już wcześniej czynników, analiza rzadko opisywanych oraz znalezienie dotychczas niezbadanych przyczyn lekooporności w padaczce u dzieci wraz z określeniem siły ich wpływu.

Materiał i metody: Badaniem objęto 152 dzieci spośród 383 hospitalizowanych na Oddziale Neurologii Dziecięcej Instytutu Centrum Zdrowia Matki Polki w Łodzi w 2012 r. z powodu padaczki. Na podstawie dokumentacji, badania neurologicznego i własnego kwestionariusza wyodrębniono dwie grupy pacjentów - z padaczką lekooporną oraz podatną na leki. Porównywano rodzaj, siłę wpływu oraz częstość występowania różnych czynników. W analizie statystycznej wykorzystano test $\chi^{2}$. Za poziom istotności przyięto $p<0,05$.

Wyniki: U 64 osób stwierdzono padaczkę lekooporną (42,1\%), a 88 miało padaczkę podatną na leczenie $(57,9 \%)$. Do czynników o największej sile wpływu na ujawnienie się lekooporności należały: duża częstość występowania napadów (V-Cramera $=0,66)$, rodzaj zespołu padaczkowego $(\mathrm{V}$-Cramera $=0,62)$, opóźnienie rozwoju psychoruchowego $(\mathrm{V}$-Cramera $=0,62)$ oraz występowanie stanów padaczkowych $(\mathrm{V}$-Cramera $=0,6)$. Rzadko lub $\mathrm{w}$ ogóle nieopisywanymi czynnikami ryzyka były infekcje ośrodkowego układu nerwowego we wczesnym dzieciństwie $(\mathrm{V}=0,41)$, powtarzające się ciężkie infekcje dróg oddechowych u dziecka $(\mathrm{V}=0,32)$ oraz choroby infekcyjne przebiegające z gorączką u matki w ciąży $(\mathrm{V}=0,31)$.

Wnioski: W badaniu potwierdzono wpływ znanych przyczyn lekooporności oraz wykazano znaczenie niedocenianych dotychczas czynników zapalnych i infekcyjnych przebiegających z gorączką, zarówno u dziecka, jak i u matki w ciąży. 


\section{Introduction}

Epilepsy is one of the most common neurological illnesses occurring in children. It is estimated that about $0.5-1 \%$ of the paediatric population suffers from this illness [1]. However, despite the fact that new epileptic drugs are designed every year, seizures in about $20-30 \%$ of patients still remain uncontrolled. Such epilepsy is referred to as drug resistant [2].

So far, no universal and detailed definition of it has been established. Thus, physicians use different criteria as regards drug resistance [3]. In response to this situation, the International League Against Epilepsy (ILAE) has recently suggested a new definition, according to which epilepsy is drug resistant when two properly selected and used therapeutic regimens (mono- or polytherapy) turn out to be ineffective in achieving permanent cessation of seizures. Therapy is considered successful if epileptic seizures do not occur for either at least three times the prior inter-seizure interval or one year (whichever is longer) [4].

Factors predisposing to drug resistance can be divided into clinical, electrophysiological, morphological, and genetic [5]. The most frequently mentioned clinical factors include the following: initial antiepileptic treatment $[6,7]$, considerable initial frequency of epileptic seizures [6, 8-12], occurrence of status epilepticus [6, 13-17], symptomatic aetiology of epilepsy $[6,16,18]$, type of epilepsy/epileptic syndrome $[11,13,14,16,19-22]$, onset of epileptic seizures before the first birthday $[13,15,18,23,24]$, abnormal results of neurological examination [8, 18, 23, 24, 25], and abnormalities detected in imaging $[18,23]$ and EEG examinations $[15,16,18]$.

Since drug-resistant epilepsy in children and teenagers constitutes a serious problem for contemporary paediatric neurology, finding the factors responsible for its unfavourable course and distinguishing the most common causes of drug resistance would allow us to apply the proper preventive measures and work out new therapies for the cases of epilepsy that have been drug resistant so far.

\section{Aim of the research}

The aim of this study was to assess the already known risk factors for drug-resistant epilepsy, ordering them according to prevalence and level of influence of drug resistance; to analyse the rarely described causes of drug resistance; and to find new clinical predictors of unfavourable course of epilepsy.

\section{Material and methods}

The study comprised 152 of all 383 children hospitalised in 2012 at the Paediatric Neurology Department of the Mother's Memorial Hospital - Research Institute in Lodz due to epilepsy. Based on the new definition of drug-resistant epilepsy proposed by the ILAE in 2009 [3], patients were divided into two groups: children with drug-sensitive epilepsy and children with drug-resistant epilepsy. In accordance with the new criteria by the ILAE, epilepsy was defined as drug-resistant if therapeutic success was not achieved and the epileptic seizures persisted despite applying two well-tolerated, properly selected, and properly administered anti-epileptic drugs (in monoor polytherapy) [3].

Analysis of the questionnaires and medical documentation, the physical examination and the interview were used to compare the level of influence of clinical factors predicting an unfavourable course of epilepsy in both groups of patients. The questionnaire comprised 40 questions concerning the factors associated with pregnancy and labour, development, onset of the illness, its course, current condition, and results of imaging and EEG examinations.

Psychomotor development in infants and small children was assessed based on psychological tests Ages and Stages Questionnaires (ASQ) and the Bayley Infant Neurodevelopmental Screener (BINS). In older children psychomotor development was assessed using the Wechsler Adult Intelligence Scale.

Medical history concerning headaches was taken from parents and children, based on a questionnaire containing questions about the frequency, duration, location, and type of pain, as well as its connection with epileptic seizures.

\section{Statistical analysis}

The data collected was analysed quantitatively and qualitatively. The result was considered statistically significant if significance level $(p)$ was $\leq 0.05$. For statistical analysis, the chi-squared $\left(\chi^{2}\right)$ test was used. Based on $\chi^{2}$ test the contingency coefficient was counted (Cramer's V), which indicates the variables' power of influence. The value of Cramer's $\mathrm{V} \geq 0.5$ signifies high association of categorical variables, $\mathrm{V}=$ $0.3-0.5$ signifies medium association, and $\mathrm{V}<0.3$ signifies low association.

\section{Results}

Among the 152 children included in the study, 64 (42.1\%) had drug-resistant epilepsy consistent with the applied criteria and 88 (57.9\%) had drug-sensitive epilepsy (Table 1).

Drug resistance was more frequent in girls (59.4\%), but the level of influence of sex on its occurrence was insignificant (Cramer's $\mathrm{V}=0.12, p=0.12$ ). On the other hand, epilepsy sensitive to pharmacotherapy was more frequent in boys, but the difference was also statistically insignificant.

Correlations between the antiepileptic treatment and the prevalence of seizures are presented in Table 2 . 
Table 1. Number of patients in age-dependent groups with drug-resistant and drug-sensitive epilepsy

\begin{tabular}{|lccc|}
\hline Age [years] & Mean age \pm SD & DRE (\%) & DSE (\%) \\
$<5$ & $3.9 \pm 1.9$ & $30(57.7 \%)$ & $22(42.3 \%)$ \\
$5-10$ & $7.2 \pm 2.1$ & $22(45.8 \%)$ & $26(54.2 \%)$ \\
$\geq 10$ & $12.4 \pm 3.4$ & $12(23.1 \%)$ & $40(76.9 \%)$ \\
All patients $(n=152)$ & $7.9 \pm 4.8$ & $64(42.1 \%)$ & $88(57.9 \%)$ \\
Chi-square test & & V-Cramer $=0.12$ & $p=0.0014$ \\
\hline
\end{tabular}

DRE - drug-resistant epilepsy, DSE - drug-sensitive epilepsy

Table 2. Number of antiepileptic drugs and prevalence of seizures in the first and last year of treatment* $(0.0000 \leq p<0.005)$

\begin{tabular}{|c|c|c|c|}
\hline \multirow[t]{2}{*}{ Factors } & \multirow[t]{2}{*}{ V-Cramer } & \multicolumn{2}{|c|}{ Number of patients } \\
\hline & & DRE & DSE \\
\hline $\begin{array}{l}\text { Number of drugs (start of treatment): } \\
\text { Without AED } \\
1 \text { AED } \\
2-3 \text { AEDs } \\
\leq 4 \text { AEDs }\end{array}$ & 0.65 & $\begin{array}{c}0 \\
0 \\
52 \\
12\end{array}$ & $\begin{array}{c}16 \\
160 \\
11 \\
0\end{array}$ \\
\hline $\begin{array}{l}\text { Number of drugs (last year of treatment): } \\
\text { Without AED } \\
1 \text { AED } \\
2-3 \text { AEDs } \\
\geq 4 \text { AEDs }\end{array}$ & 0.65 & $\begin{array}{c}0 \\
0 \\
12 \\
48\end{array}$ & $\begin{array}{c}15 \\
54 \\
57 \\
1\end{array}$ \\
\hline $\begin{array}{l}\text { Prevalence of seizures (start of treatment): } \\
\leq 1 / \text { year } \\
\text { 2-11/year } \\
\leq 1 / \text { week }\end{array}$ & 0.66 & $\begin{array}{c}0 \\
2 \\
22\end{array}$ & $\begin{array}{c}9 \\
70 \\
9\end{array}$ \\
\hline $\begin{array}{l}\text { Prevalence of seizures (last year of treatment): } \\
\leq 1 / \text { year } \\
2-11 / \text { year } \\
\geq 1 \text { /week } \\
\text { Every day }\end{array}$ & 0.66 & $\begin{array}{c}1 \\
19 \\
28 \\
16\end{array}$ & $\begin{array}{l}78 \\
9 \\
1 \\
0\end{array}$ \\
\hline
\end{tabular}

$A E D$ - antiepileptic drug, DRE - drug-resistant epilepsy, DSE - drug-sensitive epilepsy, *last year of treatment = last year of observation in the study

The most influential risk factors for drug resistance included the following: high frequency of seizures and large number of drugs taken during the first year of treatment, type of epileptic syndrome, psychomotor developmental delay, and the occurrence of status epilepticus (Cramer's $\mathrm{V} \geq 0.6$ ). High association (Cramer's $\mathrm{V}=0.5-0.6)$ was found for epilepsy aetiology, type of seizures, abnormalities in neurological examination, and abnormalities in imaging examinations (Table 3).

In a group of patients with drug-resistant epilepsy, $43(67.2 \%)$ were found to present with changes in head computed tomography (CT) and nuclear magnetic resonance (NMR). For comparison, in the group of children with satisfactory response to anti-epileptic treatment, only four patients presented with abnormalities in imaging examinations.
The most frequent developmental abnormalities found in the 12 children with drug-resistant epilepsy included agenesis of the corpus callosum (2), periventricular heterotopia, polymicrogyria, lissencephalia (2), hydrocephalus (4), and focal cortical dysplasia (2).

Other abnormalities revealed in imaging examinations included the following: post-inflammatory, ischaemic, and post-ischemic foci, vascular malformations, subependymal nodules, neoplasms, and idiopathic or post-traumatic haematomas.

A slightly lower influence on drug resistance (Cramer's $\mathrm{V}=0.3-0.5)$ was found for factors such as: presence of comorbidities, age at first epileptic seizure, headaches, lateralisation of lesions detected in EEG, past encephalitis, or cerebrospinal meningitis. All the risk factors are presented in Table 4. 
Table 3. Main factors affecting drug resistance $(0.0000 \leq p<0.005)$

\begin{tabular}{|c|c|c|c|}
\hline Clinical factors & V-Cramer & DRE (\%) & DSE (\%) \\
\hline High prevalence of seizures in the first year of treatment & 0.66 & 63 & 10 \\
\hline Large number of drugs in the first year of treatment & 0.65 & 81 & 13 \\
\hline Type of epileptic syndrome: & 0.62 & & \\
\hline 1. Roland's epilepsy and idiopathic secondary generalised epilepsies & & 5 & 55 \\
\hline 2. Epilepsy and symptomatic epileptic syndromes of a specified onset & & 45 & 9 \\
\hline 3. Epilepsy and generalised idiopathic epileptic syndromes & & 0 & 20 \\
\hline $\begin{array}{l}\text { 4. Epilepsy and generalised cryptogenic and symptomatic epileptic } \\
\text { syndromes (West's syndrome, Lennox-Gestaut syndrome, Dravet's } \\
\text { syndrome, myoclonus epilepsy with episodes of unconsciousness, } \\
\text { myoclonic astatic epilepsy) }\end{array}$ & & 31 & 1 \\
\hline $\begin{array}{l}\text { 5. Epilepsy and generalised syndromes in the course of conditions such as } \\
\text { metabolic and storage illnesses }\end{array}$ & & 16 & 4 \\
\hline 6. Unspecified syndromes & & 3 & 11 \\
\hline Psychomotor developmental delay (PDD): & 0.62 & & \\
\hline 1. Normal psychomotor development & & 3 & 78 \\
\hline 2. Mild PDD & & 30 & 15 \\
\hline 3. Moderate PDD & & 27 & 7 \\
\hline 4. Severe PDD & & 40 & 0 \\
\hline Occurrence of status epilepticus & 0.6 & 70 & 1 \\
\hline Aetiology of epilepsy: & 0.58 & & \\
\hline 1. Symptomatic & & 89 & 20 \\
\hline 2. Unknown etiology & & 11 & 40 \\
\hline Type of seizures: & 0.56 & & \\
\hline I. Focal & & 23 & 7 \\
\hline 1. Partial simple and complex & & 25 & 39 \\
\hline 2. Partial secondary generalised & & 5 & 42 \\
\hline II. Primary generalised & & 2 & 11 \\
\hline III. Polymorphic & & 45 & 1 \\
\hline Abnormal neurological examination results & 0.56 & 75 & 9 \\
\hline Abnormalities in imaging examinations & 0.51 & 70 & 14 \\
\hline
\end{tabular}

$D R E$ - drug-resistant epilepsy, DSE - drug-sensitive epilepsy

Two rarely mentioned risk factors were observed in our study: severe and frequent lower airway infection with high fever ( $\geq 5$ times per year) in children and infections with high fever in mothers during pregnancy.

\section{Discussion}

In the presented material, the factors that were most influential in causing drug resistance included the following: high frequency of seizures and large number of antiepileptic drugs applied during the first year of treatment, type of epileptic syndrome, psychomotor developmental delay, occurrence of status epilepticus, symptomatic aetiology, polymorphism of seizures, abnormalities in neurological examination, and abnormalities in imaging examinations.

High initial frequency of epileptic seizures is one of the most common causes of drug resistance. In our study this was the most influential risk factor for drug-resistant epilepsy (Cramer's V = 0.66). According to most authors, it conditions the occurrence of drug resistance to the highest degree [6, 8-12].

In our study, failure of the initial antiepileptic treatment turned out to be a comparably influential predictor of poor prognosis in epilepsy (Cramer's $\mathrm{V}=$ 0.65 ), which was also pointed out by Sillanpaa [6] and Wirrell et al. [7].

In our study, drug-resistant epilepsy was most frequent in children with generalised and cryptogenic epileptic syndromes such as West syndrome, Lennox-Gestaut syndrome, and Dravett syndrome. It was less common in children with epilepsy of localised onset, even less in epilepsies of unspecified aetiology, and least frequent in those with idiopathic epilepsies (Cramer's V = 0.62). Similar observations were described by Oskoui et al. [11], Gururaj et al. [13], French [14], Ohtsuka et al. [16], Berg et al., Geerts et al., and Schiller et al. [19-21]. 
Table 4. Factors of moderate impact on drug resistance $(0.0000 \leq p<0.005)$

\begin{tabular}{|c|c|c|c|}
\hline Clinical factors & V-Cramer & DRE (\%) & DSE (\%) \\
\hline Coexisting conditions - infantile cerebral palsy (ICP) & 0.47 & 45 & 2 \\
\hline Age at first epileptic seizure: & 0.45 & & \\
\hline 1. $<1$ years old & & 58 & 16 \\
\hline 2. 1-3 years old & & 30 & 27 \\
\hline 3. 4-13 years old & & 12 & 57 \\
\hline Headaches in childhood: & 0.44 & & \\
\hline 1. Did not occur & & 59 & 68 \\
\hline 2. Before seizures & & 16 & 5 \\
\hline 3. After seizures & & 23 & 1 \\
\hline 4. Independently of seizures & & 2 & 26 \\
\hline Left-sided lateralisation of the focus in EEG & 0.43 & 52 & 10 \\
\hline Encephalitis/cerebrospinal meningitis & 0.41 & 41 & 2 \\
\hline Hypoxic ischaemic encephalopathy & 0.39 & 67 & 25 \\
\hline Genetic syndromes & 0.38 & 30 & 1 \\
\hline Cerebral malformations & 0.38 & 31 & 2 \\
\hline Febrile convulsions at body temperature $\leq 38.5^{\circ} \mathrm{C}$ & 0.37 & 28 & 1 \\
\hline Family history of epilepsy & 0.32 & 48 & 2 \\
\hline $\begin{array}{l}\text { Severe infections of lower airways with high body temperature } \\
\text { in a child }-\geq 5 \text { times per year }\end{array}$ & 0.32 & 64 & 38 \\
\hline Severe infections with high body temperature in pregnant women & 0.31 & 58 & 34 \\
\hline
\end{tabular}

$D R E$ - drug-resistant epilepsy, DSE - drug-sensitive epilepsy

Delay in psychomotor development is one of the most frequent causes of drug resistance. In our study this was also one of the most influential risk factors for drug-resistant epilepsy (Cramer's $\mathrm{V}=0.62$ ). This view is shared by most authors [6, 8, 13, 22, 25]. According to Camifield, normal intellectual development is fundamental for good prognosis in epilepsy [26]. It has also been confirmed that a long-lasting persistence of epileptic seizures and occurrence of status epilepticus affects intellectual development [27-32].

Medical history of status epilepticus was another important predictor of drug resistance. Its occurrence in early childhood was strongly correlated with later drug resistance (Cramer's $\mathrm{V}=0.6$ ). Studies by other authors such as Sillanpaa [6], Ramos-Lizana et al. [8], Mohanraj and Brodie [10], and Gurruraj et al. [13] also revealed the relation between status epilepticus and drug-resistant epilepsy.

Another factor worsening the prognosis is the polymorphism of seizures in the course of epilepsy. In the analysed group the most powerful predictors of drug resistance included polymorphic epileptic seizures and focal seizures, mainly partial complex ones (Cramer's V = 0.56). Chawla et al. [24] and Go and Snead [33] pointed out the influence of such seizures on the occurrence of drug resistance in the treatment of epilepsy. The literature seems to indicate that epilepsy of symptomatic aetiology heralds its unfavourable course (Cramer's V
$=0.58$ ), which was proven by Sillanpaa [6], Akhondian et al. [18], and Go and Snead [33].

Another important risk factor for drug resistance confirmed in our study was abnormal neurological examination result (diagnosis of a neurological syndrome: pyramidal syndrome, extrapyramidal syndrome, cerebellar syndrome, hypotonia) (Cramer's V $=0.56$ ). According to most authors, an abnormal result of a neurological examination is a significant risk factor for drug resistance in epilepsy [13, 18, 23-25].

The authors also pointed out the relation between drug resistance and structural and developmental changes in the central nervous system revealed in CT and NMR examinations (Cramer's V $=0.51$ ). Similar observations were also made by different authors, including Sillanpaa and Schmidt [9], Ramos-Lizana et al. [25], and Guerrini et al. [32]. Guerrini et al. analysed the problem of drug-resistant epilepsy in several specific developmental malformations of the cerebral cortex, such as hemimegalencephaly, focal cortical dysplasia, bilateral schizencephaly, periventricular heterotopias, lissencephaly, and polymicrogyria [32].

Another frequently described factor causing drug resistance is early onset of epileptic seizures (Cramer's $\mathrm{V}=0.45)$, which was confirmed in our study $[10,13$, $17,23,34,35]$.

Drug resistance in epilepsy has also been demonstrated to be related with febrile convulsions observed 
when body temperature was below $38.5^{\circ} \mathrm{C}$ (Cramer's $\mathrm{V}=0.37$ ). This was also confirmed by Geerts et al. [36].

According to Go, Gurruraj, and Kwan and Brodie $[13,17,33]$, positive family history for epilepsy also prevents treatment of epilepsy from being successful, which was confirmed in the group of children analysed by us (Cramer's V $=0.32$ ).

Encephalitis/cerebrospinal meningitis in early childhood is another important risk factor for drug resistance in epilepsy, which requires special attention (Cramer's V $=0.32$ ). Melila et al. demonstrated that abnormalities in the CNS resulting from blood-brain barrier dysfunction after encephalitis in early childhood can cause continuous inflow of cytokines, antibodies, and other blood components. Consequently, they increase the frequency of epileptic seizures and the prevalence of their neurological sequelae [34] A growing number of scientific reports support the hypothesis which emphasises the significance of immunological aetiology of epilepsy. The influence of immune system activity on epileptogenesis was confirmed in studies that demonstrated that during the formation of an epileptic focus we can observe a proliferation and activation of astrocytes and microglia, an increase of blood-brain barrier permeability, and an increase of proinflammatory factors - IL-1B, TNF- $\alpha$, and IL-6 [37]. Most recent studies have shown that cyclooxygenase-2, induced by proinflammatory factors and responsible for prostaglandin synthesis, regulates the activity of P-glycoprotein - a protein found in the endothelial top layer of capillary vessels included in the blood-brain barrier. P-glycoprotein plays a crucial role in the phenomenon of multidrug resistance; therefore changes in its activity affect the resistance to antiepileptic drugs [38]. More evidence confirming the relation between drug resistance and inflammatory factor is the reaction of drug-resistant epileptic syndromes to treatment with ACTH, glycocorticosteroids, and large doses of intravenously administered immunoglobulins [39].

Additionally, there were risk factors for drug resistance in epilepsy, which have so far been rarely mentioned or not mentioned at all in literature but were found to be significant in our study. This includes infections with high fever in the mother during pregnancy (58\% of children with drug-resistant epilepsy), inflammatory diseases and severe infections involving high fever in the child's early childhood (64\% of children with drug-resistant epilepsy). The influence of these factors was not high (Cramer's $\mathrm{V}=0.31$ and 0.32 ) but they were found in a large proportion of ill children.

Among the patients included in the study there were no cases of drug resistance related to labour and perinatal pathologies. Studies conducted by Akhondian et al. [18] in a population of patients at developmental age indicated that drug resistance is more common in males, whereas the study conducted in
2013 by Kalinin et al. [40] in a population of adults showed a higher prevalence of drug resistance in females than males.

\section{Conclusions}

The study confirmed the influence on drug resistance of already-known factors such as the follwing: high frequency of seizures and a large number of antiepileptic drugs applied during the first year of treatment, type of epileptic syndrome, psychomotor developmental delay, occurrence of status epilepticus, symptomatic aetiology, polymorphism of seizures, abnormalities in neurological examination, and abnormalities in imaging examinations. Inflammatory and infectious illnesses (especially encephalitis/cerebrospinal meningitis) in early childhood worsen the prognosis in epilepsy. It has been proven that drug resistance is related with risk factors not recognised so far such as severe infections involving high fever in early childhood (at least five times in a year) and severe infections with high fever during the mother's pregnancy.

\section{References}

1. Wendorff J. Czynniki ryzyka padaczki lekoopornej u dzieci [Polish]. Klin Pediatr 2003; 11: 251-5.

2. Jóźwiak S. Współczesne poglądy na klasyfikację, patogenezę i postępowanie w padaczce lekoopornej [Polish]. Wiad Lek 2007; 60: 258-64.

3. Kwan P, Arzimanoglou A, Berg AT, et al. Definition of drug resistant epilepsy: consensus proposal by the ad hoc Task Force of the ILAE Commission on Therapeutic Strategies. Epilepsia 2010; 51: 1069-77.

4. Wiebe S. Definition of drug resistant epilepsy: is it evidence based? Epilepsia 2013; 54 Suppl 2: 9-12.

5. Wypych M, Andrzejczak-Sobocińska A, Tomalska J. Padaczka lekooporna - kryteria rozpoznania i leczenie [Polish]. Neurologia 2005; 10: 58-63.

6. Sillanpaa M. Remission of seizures and predictors of intractability in long - term follow up. Epilepsy 1993; 34: 930-6.

7. Wirrell E, Camfield C, Camfield P, et al. Prognostic significance of failure of the initial antiepileptic drug in children with absence epilepsy. Epilepsia 2001; 42: 760-3.

8. Ramos-Lizana J, Aguilera-López P, Aguirre-Rodriguez J, et al. Early prediction of refactory epilepsy in childhood. Seizure 2009; 18: 412-6.

9. Sillanpaa M, Schmidt D. Naturial history of treated childhood-onset epilepsy: prospective, long-term population-based study. Brain 2006; 129: 617-24.

10. Mohanraj R, Brodie MJ. Diagnosing refractory epilepsy: response to sequential treatment schedules. Eur J Neurol 2006; 13: 277-82.

11. Oskoui M, Webster RI, Zhand X, et al. Factors predictive of outcome in childhood epilepsy. J Child Neurol 2005; 2011: 898-904.

12. Thang-Wai R, Oskoui M, Webster R, et al. Outcomes in pediatric epilepsy: seeing through the fog. Pediatr Neurol 2005; 33: 244-50. 
13. Gururaj A, Sztriha L, Hertecant J, et al. Clinical predictors of intractable childhood epilepsy. J Psychosom Res 2006; 61: 343-7.

14. French JA. Refractory epilepsy: clinical overview. Epilepsia 2007; 48 Suppl 1: 3-7.

15. Berg AT, Shinnar S, Levy SR, et al. Early development of intractable epilepsy in children: a prospective study. Neurology 2001; 56: 1445-52.

16. Ohtsuka Y, Yoshinaga H, Kobayashi K, et al. Predictors and underlying causes of medically intractable localization-related epilepsy in childhood. Pediatr Naurol 2001; 24: 209-13.

17. Kwan P, Brodie MJ. Early identification of refractory epilepsy. N Engl J Med 2000; 342: 314-9.

18. Akhondian J, Heydarian F, Jafar SA. Predictive factors of pediatric intractable seizures. Arch Iran Med 2006; 9: 236-9.

19. Berg AT, Levy SR, Navotny EJ, et al. Predictors of intractable epilepsy in childhood: a case control study. Epilepsia 1996; 37: 24-30,

20. Geerts A, Arts WF, Stroink H, et al. Course and outcome of childhood epilepsy: 15-year follow-up of the Dutch Study of epilepsy in childhood. Epilepsia 2010; 51: 1189-97.

21. Schiller Y, Najjar Y. Quantifying the response to antiepileptic drugs: effect of past treatment history. Neurology 2008; 70: 54-65.

22. Berg AT, Vickrey BG, Testa FM, et al. How long does it take for epilepsy to become intractable? A prospective investigation. Ann Neurol 2006; 60: 73-9.

23. Kwong KL, Sung WY, Wong SN, et al. Early predictors of medical intractability in childhood epilepsy. Pediatr Neurol 2003; 29: 46-52.

24. Chawla S, Aneja S, Kashyap R, et al. Etiology and clinical predictors of intractable epilepsy. Pediatr Neurol 2002; 3: 186-91.

25. Ramos-Lizana J, Rodriguez-Lucenilla M, Aguilera-López P, et al. A study of drug-tesistand childhood epilepsy testing the new ILAE criteria. Seizure 2012; 21: 266-72.

26. Camfield PR, Camfield CS, Gordon K, Dooley JM. If a first antiepileptic drug fails to control a child's epilepsy, what are the chances of success with the next drug? J Pediatr 1997; 131: 821-4.

27. Fastenau PS, Johnson CS, Perkins SM, et al. Neruopsychological status at seizure onset in children: risk factors for early cognitive deficits. Neurology 2009; 73: 526-34.

28. Tiege X, Laufs H, Boyd SG, et al. EEG-fMRI in children with pharmacoresistant focal epilepsy. Epilepsia 2007; 48: 385-9.

29. Aldenkamp AP, Arends J, Verspeek S, et al. The cognitive impact of epileptiform EEG-discharges; relationship with type of cognitive task. Child Neuropsychol 2004; 10: 297305.

30. Jóźwiak S, Kotulska K, Domańska-Pakieła D, et al. Antiepileptic treatment before the onset of seizures reduces epilepsy severity and risk of mental retardation in infants with tuberous sclerosis complex. Eur J Paediatr Neurol 2011; 15: 424-31.

31. Bombardieri R, Pinci M, Moavero R, et al. Early control of seizures improves long-term outcome in children with tuberous sclerosis complex. Eur J Paediatr Neurol 2010; 14: 146-9.

32. Guerrini R, Holthausen H, Parmegani L, et al. Epilepsy and malformations of cerebral cortex. In: Epileptic syndromes in infancy, childhood and adolescence (3rd ed.).
Roger J, Bureaum M, Drawet C, et al. John Libbey. London 2002; 457-79.

33. Go C, Snead OC. Pharmacologically intractable epilepsy in children: diagnosis and preoperative evaluation. Neurosurg Focus 2008; 25: E2.

34. Melila M, Suriadi-Yukitoshi T, Shigeko N, et al. Zaburzenia funkcji bariery krew - mózg u chorych z padaczką po przebytym zapaleniu mózgu [Polish]. Epileptologia 2012; 20: 23-4.

35. Marchi N, Granata T, Janigro D. Inflammatory pathways of seizure disorders. Trends Neurosci 2014; 37: 55-6.

36. Geerts A, Arts WF, Stroink H, et al. Course and outcome of childhood epilepsy: a 15-year follow-up of the Dutch Study of Epilepsy in Childhood. Epilepsia 2010; 51: 1189-97.

37. Najjar S, Pearlman D, Miller DC, et al. Refractory epilepsy associated with microglial activation. Neurologist 2011; 17: 249-54

38. van Vliet EA, da Costa Araujo S, Redeker S, et al. Bloodbrain barrier leakage maylead to progression of temporal lobe epilepsy. Brain 2007; 130: 521-34.

39. Billian AD, Witters P, Cenlemans B, et al. Intravenous immunoglobulins in refractory childhoodonset epilepsy: effects on seizure frequency, EEG activity and cerebrospinal fluid cytokine profile. Epilepsia 2007; 48: 1739-49.

40. Kalinin W, Zemlianaja A, Żelaznowa W, et al. Neurobiologiczne i kliniczne czynniki rokownicze remisji i skuteczności leczenia przeciwpadaczkowego $\mathrm{w}$ padaczkach częściowych [Polish]. J Epileptol 2013; 21: 7-10.

\section{Address for correspondence:}

\section{Waldemar Brola MD, PhD}

Neurology Department with Stroke Unit Specialist Hospital

ul. Gimnazjalna 41, 26-200 Końskie, Poland

Phone: +48 4139022 59, +48 601313415

Fax: +48 413902364

E-mail: wbrola@wp.p 